\title{
Effect of Dietary Vitamin A on Resistance to Experimental Escherichia coli Infection of Uterus in Rats
}

Toshio INABA, Akiko INOUE ${ }^{1)}$, Yoshihisa NAKANO ${ }^{2)}$, and Junichi MORI

Department of Animal Reproduction, ${ }^{1)}$ Department of Veterinary Surgery, and ${ }^{2)}$ Department of Agricultural Chemistry, College of Agriculture, University of Osaka Prefecture, Sakai, Osaka 591, Japan

(Received 21 April 1989/Accepted 15 August 1989)

Jpn. J. Vet. Sci. 51(6): 1247-1249, 1989

KEY WORDS: uterine infection, vitamin A.

Vitamin A is essential for vision, growth, and reproduction $[1,12]$. Although the role of vita$\min \mathrm{A}$ in the visual process has been elucidated, the role of vitamin $\mathrm{A}$ in regulating other physiological processes, especially uterine function, is less clear. Chew et al. $[2,6]$ reported that mice and cows deficient in vitamin A will show increased frequency and severity of mammary gland infections. Based on these findings, vitamin A may have a similar protective effect against uterine infections. The present study was undertaken to test this hypothesis by examining the severity of uterine infections in rats fed a vitamin A-deficient diet after intra-uterine infusion with Escherichia coli (E. coli).

Female Wistar rats, 2 months old, were ovariectomized 2 days before the start of experiment. Animals were assigned randomly to receive a vitamin A-deficient diet (Table 1) or a vitamin A-deficient diet supplemented with $100 \mathrm{IU}$ or 5,000 IU of vitamin A per rat per day for 15 days. The vitamin A-deficient diet prepared as described by Chew et al. [2] was supplied by Oriental Yeast Co. LTD (Tokyo).

The supplements were prepared to contain 100 $\mathrm{IU}$ and 5,000 IU of retinol acetate per $0.5 \mathrm{~m} l$ corn oil and given to the rats using a cathether. Water and vitamin A-deficient diet were provided ad libitum. After being on the experimental diet for 12 days, rats were injected i.m. daily with $0.1 \mu \mathrm{g}$ estradiol-17 $\beta$ dissolved in $0.1 \mathrm{~m} l$ of corn oil for 2 days. On the following day, a $E$. coli suspension $\left(10^{6} \mathrm{CFU}\right)$ was inoculated into the lumen of one uterine horn [9]. The other horn was left noninoculated. Both uterine horns of each animal were ligated at the cervical ends to prevent possible drainage of uterine contents. A strain of E. coli $(0: 25, \mathrm{H}:-)$ isolated from the pus of a dog suffering from pyometra was used [9]. All animals subsequently were sacrificed on the next day, and plasma and liver were obtained for vitamin $\mathrm{A}$ analysis. Plasma and liver vitamin $\mathrm{A}$ (total vitamin A) were extracted by the method of Johnston and Chew [6] and the method of Underwood et al. [10], respectively and determined by the high performance liquid chromatography with ODS C18 column $(46 \times 150 \mathrm{~mm}, 5$ $\mu \mathrm{m})$ [4]. The inoculated uterine horn was flushed with $1.0 \mathrm{ml}$ of sterile saline solution and the number of leukocytes in uterine flushings, representing the magnitude of purulent inflammation, was counted [9]. The noninoculated uterine horn was weighed with a torsion balance. Then, the uterine luminal fluid was eliminated, and the weight of the horn was measured again. The secretion index was calculated with the following formula: Secretion index $=[(\mathrm{B}-\mathrm{A}) \times 100] / \mathrm{A}$, where A represents the weight of uterine horn after the elimination of uterine luminal fluid and $B$ is the weight of uterine horn before the elimination. Results of the assays were analyzed for significance by Student's $t$ test.

The changes of concentration of vitamin $\mathrm{A}$ in

Table 1. Composition of vitamin A-deficient experimental diet

\begin{tabular}{lc}
\hline Ingredients & $\%$ Diet \\
\hline Corn starch & 38 \\
Casein (vitamin-free) & 25 \\
Alpha starch & 10 \\
Cellulose powder & 8 \\
Linolic salad oil & 6 \\
Mineral mix ${ }^{\text {a) }}$ & 6 \\
Granulated sugar $_{\text {Vitamin premix }}^{\text {b) }}$ & 5 \\
\hline
\end{tabular}

a) Mineral mix contained the following minerals in $\mathrm{mg}$ per $100 \mathrm{~g}$ of diet: phosphate, 990; calcium, 560; potassium, 420; sodium, 250; magnesium, 74.9; iron, 27.0; zinc, 5.1; manganese, 2.2; copper, 0.57 ; iodine, 0.46 .

b) The vitamin premix contained the following vitamins in $\mathrm{mg}$ per $100 \mathrm{~g}$ of diet: vitamin $\mathrm{B}_{1}$, 2.4; vitamin $\mathrm{B}_{2}, 8.0$; vitamin $\mathrm{B}_{6}, 1.6$; vitamin $\mathrm{B}_{12}, 0.001$; vitamin $\mathrm{C}, 60.0$; vitamin $\mathrm{D}_{3}, 0.005$; vitamin $\mathrm{E}, 10.0$; vitamin $\mathrm{K}_{3}, 10.4$; biotin, 0.04 ; folic acid, 0.4 ; Ca-pantothenate, $10.0 ; p$ aminobenzoic acid, 10.0; niacin, 12.0; inositol, 12.0; choline- $\mathrm{Cl}, 400.0$. 
plasma and liver of rats fed vitamin A deficient diet are shown in Fig. 1. Plasma vitamin A levels in these rats changed little during 40 days, while liver vitamin $\mathrm{A}$ levels decreased significantly in later than 15 days $(\mathrm{P}<0.01)$.

Vitamin A concentration in plasma and liver, and number of leukocyte and secretion index in uterus of rats inoculated $E$. coli after being on the vitamin A-deficient diet for 15 days are shown in Table 2. The final body weights and the mean of plasma vitamin A values were not significantly different among the rats supplemented with 0 , 100 , and 5,000 IU of vitamin A. On the contrary, as the dietary supplementation by vitamin $\mathrm{A}$ increased from 0 to 5,000 IU per day, there was an increase in liver vitamin A levels. E. coli inoculated to vitamin A-unsupplied rats induced purulent endometritis and accumulated large amount of leukocytes in one day after inoculation. On the other hand, vitamin Asupplemented rats inoculated E. coli did not suffered from purulent endometritis and accumulated small amount of leukocytes in uterus. These results suggest that vitamin A prevents manifestation of purulent endometritis. In this respect, it is reported that diets deficient or inadequate in vitamin $\mathrm{A}$ increase the risk of development of certain epithelial tumours [3, 13].

The mechanisms by which uterine infection does not bring about endometritis under the supplementation of vitamin A still remain to be elucidated. The decreased occurrence of purulent endometritis in vitamin A-supplemented rats can not be explained by an increased amount of plasma vitamin $\mathrm{A}$, since in these rats plasma vitamin $\mathrm{A}$ levels were not significantly different from those of vitamin A-unsupplied rats. A possible explanation may be that circulatory vitamin A may provide more effectively in uterine tissue of vitamin A-supplemented rats for the prevention of uterine infection [11].

Though estrogen enhances defense mechanisms in uterus [9], it is possible that a response for estrogen is lowered in uterus of vitamin A-unsupplied rats. To examine this possibility, we determined the amount of secretion from uterus as a maker for estrogen response. As shown in Table 2, the amount of secretion from

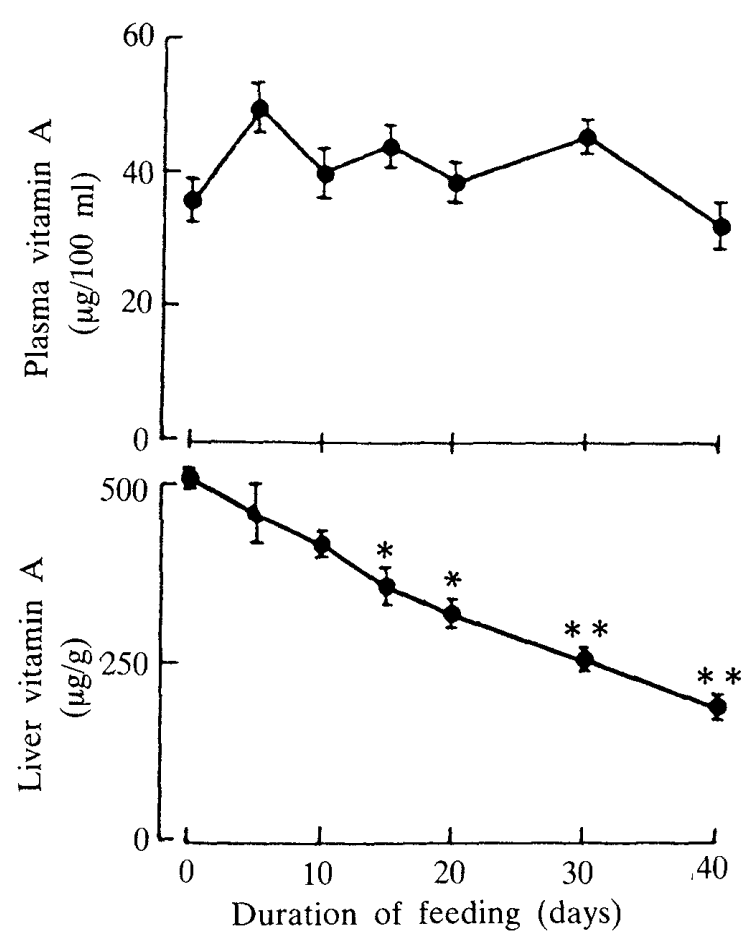

Fig. 1. Concentration of vitamin $\mathrm{A}$ in plasma and liver of rats fed vitamin A deficient diet. The points and vertical lines represent means \pm SEM of 4 to 16 rats. ${ }^{*} \mathrm{P}<0.01,{ }^{* *} \mathrm{P}<0.001$.

Table 2. Effect of vitamin A supplement on vitamin A concentration in plasma and liver, number of leukocytes and secretion index in uterus of rats fed vitamin $A$ deficient diet for 15 days

\begin{tabular}{cclllll}
\hline $\begin{array}{l}\text { Vitamin } \\
\begin{array}{l}\text { A-supple- } \\
\text { mented } \\
\text { (IU/day) }\end{array}\end{array}$ & $\mathrm{n}$ & $\begin{array}{l}\text { Final } \\
\text { body } \\
\text { weight } \\
(\mathrm{g})\end{array}$ & $\begin{array}{l}\text { Plasma } \\
\text { vitamin } \mathrm{A} \\
(\mu \mathrm{g} / 100 \\
\mathrm{ml})\end{array}$ & $\begin{array}{l}\text { Liver } \\
\text { vitamin A } \\
(\mu \mathrm{g} / \mathrm{g})\end{array}$ & $\begin{array}{l}\text { No. of } \\
\text { leukocytes } \\
/ 0.02 \mu \mathrm{l} \\
\text { of the } \\
\text { flushings }\end{array}$ & Secretion \\
\hline 0 & 8 & $155 \pm 4^{\mathrm{a})}$ & $38.6 \pm 1.9$ & $318 \pm 28$ & $103.8 \pm 31.0$ & $68.8 \pm 18.2$ \\
100 & 5 & $158 \pm 6$ & $34.2 \pm 1.8$ & $503 \pm 18^{*}$ & $83.7 \pm 8.5$ & $72.1 \pm 28.5$ \\
5,000 & 10 & $161 \pm 5$ & $35.9 \pm 2.5$ & $1450 \pm 298^{*}$ & $25.7 \pm 4.8^{*}$ & $82.6 \pm 8.6$ \\
\hline
\end{tabular}

a) Mean \pm SEM.
* $\mathrm{P}<0.01$. 
noninoculated horns in vitamin A-unsupplied rats was not significantly different from that of vitamin A-supplemented rats.

Recent findings suggest a possible relationship between vitamins and retained fetal membranes (RFM) in dairy cows [5]. Supplemental vitamin $A$ [8] or E [7] reduced RFM incidence in cows in which vitamin deficiency was suspected. Our observations illustrate the importance of a dietary intake of vitamin $\mathrm{A}$ for the prevention of uterine infection. It is possible, therefore, that dairy cows fed low vitamin A will respond in a similar manner.

ACKNOWLEDGEMENTS. This study was supported in part by a Grant-in-Aid for Encouragement of Young Scientist No. 59760222 from the Ministry of Education, Science and Culture of Japan.

\section{REFERENCES}

1. Bauernfeind, J. C. 1983. World Rev. Nutr. Diet. 41: $110-199$.
2. Chew, B. P., Luedecke, L. O., and Holpuch, D. M. 1984. J. Dairy Sci. 67: 2566-2570.

3. Cohen, S. M., Wittenberg, J. F., and Bryan, G. T. 1976. Cancer Res. 36: 2334-2339.

4. Hosotani, K. and Kitaoka, S. 1984. J. Jpn. Soc. Nutr. Food Sci. 37: 519-524 (in Japanese with English Summary).

5. Inaba, T., Inoue, A., Shimizu, R., Nakano, Y., and Mori, J. 1986. Jpn. J. Vet. Sci. 48: 505-508.

6. Johnston, L. A. and Chew, B. P. 1984. J. Dairy Sci. 67: 1832-1840.

7. Julien, W. E. and Conrad, H. R. 1976. J. Dairy Sci. 59: 1954-1959.

8. Nicholson, J. W. G. and Cunningham, H. M. 1965. Can. Vet. J. 6: 275-281.

9. Nishikawa, Y. and Baba, T. 1985. Infect. Immun. 47: 311-317.

10. Underwood, B. A., Loerch, J. D., and Lewis, K. C. 1979. J. Nutr. 109: 769-806.

11. Wolf, G. 1984. Physiol. Rev. 64: 873-938.

12. Zile, M. H. and Cullum, M. E. 1983. Proc. Soc. Exp. Biol. Med. 172: 139-152.

13. Zile, M. H., Cullum, M. E., Roltsch, I. A., DeHoog, J. V., and Welsch, C. W. 1986. Cancer Res. 46: 3495-3503.

\section{要 約}

ラット子宮の実験的大腸菌感染に及ぼす食餌性ビタミン A の影響（短報）：稲葉俊夫・井上明子1）・中野 長久 ${ }^{2)}$ ・森 純一 (大阪府立大学農学部家畜臨床繁殖学教室, ${ }^{1)}$ 家畜外科学教室, ${ }^{2)}$ 栄養化学教室) 一ービタミ ン A 矢乏食を与えたラットの子宮内に大腸菌を接種すると，血槳中ビタミン A 量はビタミン $\mathrm{A}$ 給与ラットのそ れと比べて有意な差が認められなくても，肝中ビ夕ミン $\mathrm{A}$ 量は減少し，子宮の感染抵抗性の有意な低下が生じ ることが認められた，さらに，同ラットにビタミン A を補給することにより，肝中ビタミン A 量は増加し，子 宮の感染抵抗性が上昇することが認められた。 